\title{
Value Chain Analysis and Community-Based Strategies of Chirayita (Swertia chirayita) in Eastern Nepal
}

\author{
Gaire, Damodar ${ }^{1 *}$, Yadav, Bijay Kumar ${ }^{1}$ and Kattel, Rishi Ram² \\ ${ }^{1}$ Tribhuvan University, Nepal \\ ${ }^{2}$ Agriculture and Forestry University, Nepal
}

Submission: May 07, 2019; Published: June 11, 2019

*Corresponding author: Gaire, Damodar, Assistant Professor, Tribhuvan University, Institute of Forestry, Nepal

\begin{abstract}
The study has attempted to conduct the study on value chain analysis of Swertia chirayita, a perennial herb, is the major source of income in rural households of eastern Nepal. The field assessment for the Chirayito value chain was conducted out in Taplejung district of Nepal. The information was primarily collected through Focus Group Discussions (FGDs) and Key Informants Interview. Interview with middleman and buyers were also carried out in the district headquarter and directly in the fields. It was observed that Chirayita market is decreasing as compared to the previous years. Therefore, Chirayita farmers have searched for the alternative crops for sustainable income in their own locations. However, some Chirayita farmers are still hopeful about the stability of Chirayita prices so that they would convert their uplands and sloppy lands to Chirayita farm for enhancing their income which ultimately helps for sustainable livelihoods. The Chirayita price was NRs 250 to NRs 375/kg in 2018 in Taplejung district. In 2015, farmers used to sell the dried Chirayita at the rate of NRs 650/kg which is a huge difference. The local traders have sold the dried Chirayita to Bangladeshi buyers up to $5 \%$ of total production. Likewise, $40 \%$ market in China and $50 \%$ market in India. Less than $5 \%$ of Chirayita production has been used for different medicinal purposes (Typhoid fever, cough, diarrhea, gastric, etc.) for home consumption. Nowadays, traders are interested to sell their Chirayita to Chinese buyers due to high margin or profit. The cost of production per Ropani land was calculated as NRs. 14455 after discussing with local farmers in Sirungkhim, Taplejung. Local farmers have also highlighted the products of Chirayita which can easily be sold in the markets such as Chirayita herbal tea, powder form of Chirayita (for gastric, ulcer, jaundice, blood sugar, blood pressure, typhoid fever patients), Chirayita face wash (for cosmetic items) and other herbal extracts as required. Therefore, concerned authorities should encourage to farmers, cooperative members and other concerned stakeholders create an environment for value addition of Chirayita which ultimately helps to create the income generation of poor and disadvantaged people sustainably.
\end{abstract}

Keywords: Value chain; Chirayita; Cultivation; Cooperative; Livelihoods; Nepalese Rupees (NRs)

\section{Introduction}

Of the many forest products, Chirayita is one the most traded forest products in Nepal. The botanical name of the Chirayita is "Swertia chirayita (Roxb. ex Fleming) Karsten". Locally, it is known as "Tite or Pothi Chirayita or Tikta". Chirayita is a perennial herb found in the temperate regions of Nepal. This is also one of the prioritized medicinal plants of Nepal [1]. Apart from the collection of wild, it is now cultivated in most of the eastern districts of Nepal [2]. Chirayita or Swertia comprises 100 species (Airy Shaw, 1993) of which 32 species are recorded from 40 districts of Nepal.

Around nine species of Swertia are reported to be traded in different trade centers of Nepal. Among them Swertia chirayita is considered as superior in quality. Others are Swertia alata, Swertia ungustifolia, Swertia ciliate, Swertia purpurascens,
Swertia dilatata, Swertia multicaulis, Swertia nervosa, Swertia racemosa, and Swertia tetragona and all these have business value as well. The plant is used as a bitter tonic in treatment of fever and for curing various skin diseases. S. chirayita has an established domestic (Indian) and international market, which is increasing at a rate of $10 \%$ annually [3].

Regional demand for S. chirayita is very high, particularly the export (and presumably re-export) trade from India to the European Union (EU) and the cross-border trade from Nepal to India (Kunwar et al., 2013) and Tibet [4]. Recent review articles have comprehensively described the traditional uses, phytochemistry and pharmacology of S. chirayita, but have not covered trade in any detail $[5,6]$. Nevertheless, this species is one of the 32 high priority medicinal plants identified by the Government 
of India's National Medicinal Plant Board (Shukla et al., 2017) [7] and it is also included in the prioritized 30 medicinal plant species for economic development by the Government of Nepal [8].

About 90 tonnes of Chirayita have been traded from the eastern development region of Nepal, whereas only 1.5 tones have been traded from midwestern $[9,10]$. Therefore, east part of Nepal has the highest potential for cultivation of the Chirayita as a pocket area. Chirayita is predominantly found in most of the Northern rural municipalities in Taplejung district. According to data received from DFO Taplejung, the allowable harvesting amount of Chirayita is 39.5 tones. However, 26.3 tonnes of dried Chirayita have been transported in the fiscal year 2074/2075 which is comparatively low compared to allowable harvesting amount. A market Study of tradable and economically important medicinal and aromatic plants of Eastern Nepal showed that 2,32,226 kg of Chirayita exports from Eastern Nepal [11].

\section{Rationale of the Study}

Due to Chirayita price fluctuation, the farmers have looked up for alternative cultivation. Nowadays, China`s market is increasing while comparing to India and Bangladesh. The present farm gate price of Chirayita is NRs $250 / \mathrm{Kg}$ which is $100 \%$ lower price than the past year (According to the field survey, 2018). Even the price is dropping, it fetches up to NRS 550 if it can be shipped to northern neighbor China. In 2015, farm gate price for Chirayita was NRs 600. The international price of Chirayita is increasing in every year. The main reason of price dropping was due to middleman and agents. Moreover, middlemen have entered the trade who are hard bargainers, and farmers have not been able to make as much from their crops as they used to. The middlemen sell the herb to Chinese traders with a big markup.

There is likely unreported cross-border trade from Nepal into India and China and from Bhutan into Tibet. He et al. [12] in their study of the Nepal- China medicinal plants trade gives detailed examples of under-reporting. They also record that there are about 235 local paths along the $1400 \mathrm{~km}$ long border between Nepal and China that enable local people to cross in order to trade.

Based on value-chain analysis and cost-benefit assessments, S. chirayita cultivation has been shown to be profitable in Nepal. However, since the first cost-benefit assessment was done (2013), prices dropped from NRs 750/kg on April 2013 to a low of $250 \mathrm{NRs} / \mathrm{kg}$ in December 2017). Taking inflation into account further highlights the steep decline in the profitability for local farmers, who have limited options for value-adding. Consequently, farmers prefer to grow more profitable alternative crops [13]. For the functional upgrading of Chirayita, actors like farmers, young entrepreneurs, and traders play the vital role in the VC analysis of Chirayita. The present function of farmers was to cultivate the Chirayita indigenously. Modern techniques of cultivation are required, including TOT. Traders have accelerated to Birtamod and Tibet border. Therefore, further Chirayita networks should be established, including sustainable seedling supply. In the present situation, cooperatives are engaged in savings and credit. The cooperative should provide the loan to farmers so that cultivators can stock Chirayita and sell it at the right time (Figure 1).

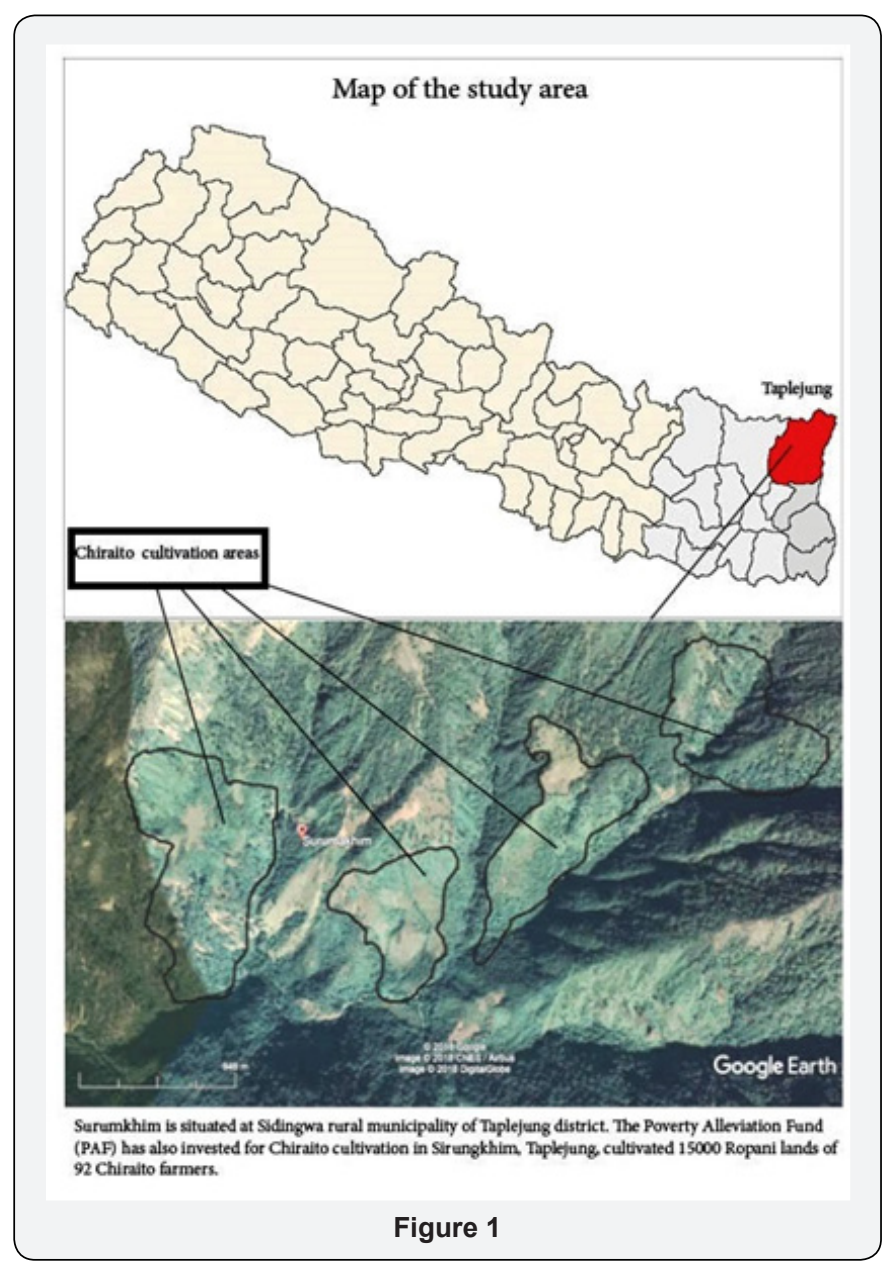

\section{Materials and Methods}

The main objective of the study is to provide a comprehensive Value Chain Analysis of Chirayita for both market and social benefit. Chirayita farmers, middleman, district traders, regional traders and international traders are the major stakeholders of the study. We focused on Chirayita production in Taplejung distrit where PAF has been implementing Chirayita Cultivation Project since 2016. The personal interview, Focus group discussion among the Chirayita cultivators, field verification and questionnaire survey were the key methods for data collection. The secondary data were reviewed related to Chirayita study. The PAF working area (Taplejung district) were selected for Chirayita value chain analysis. However, the study was able to review the international market of $S$. chirayita using interview and publication of international journals. 


\section{Results and Discussion}

\section{Production and marketing}

Nepal contribute the $45 \%$ of dried Chirayita in the world market. The government of Nepal prioritizes Chirayita as having potential for economic development and has set a high priority on its research and cultivation. The plant is collected from natural forest with the permission of the respective District Forest Offices (DFO), with collectors paying a tariff of
NRs 15per kg. The government of Nepal earned NRs 2, 31, 640 as revenues by issuing collection permits from different DFOs in the fiscal year $2073 / 74$. Tariff or duty is not required to be paid for cultivating species, the cultivated areas and estimated productivity need to be verified by rangers or DFOs, National Parks or Conservation Area Offices. The highlighted black shade represents the Chirayita areas in the world. Nepal is the major country to supply the Chirayita (about $45 \%$ ) in the world market (Figure 2).
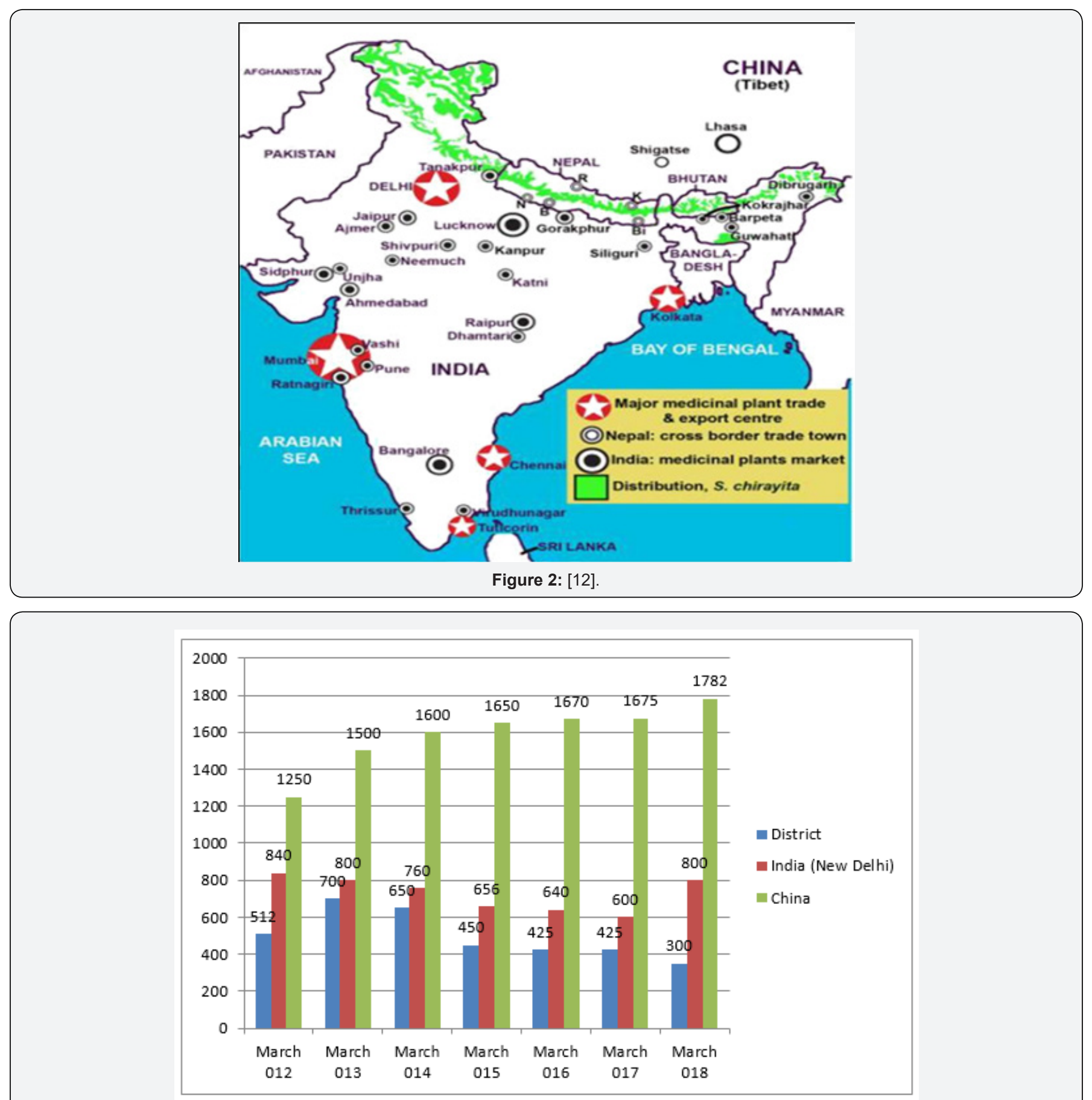

Figure 3: [14]. 


\section{Discussion}

Government of Nepal (GON) has earned about US\$ 61,000 though Chirayito Royalties which was only recorded from the DFO of all districts (DOF, 2016). The royalties of Chirayita from community forestry has deposited in the fund of CFs. About 766 MT dried Chirayita have been estimated through cultivation in Taplejung district. About 26MT Chirayita have been traded in 2017. Farmer can increase the production through modern Chirayita cultivation techniques. The production doubles through transferring the seedlings from nurseries rather than directly broadcasting in the field. The production point of view, Chirayita farmers cultivate with the average land of 9.5 Ropani, and average production of $1520 \mathrm{Kg}$ in favorable condition. Regarding the marketing, India, China and Bangladesh are the major international markets where buyers come in regional wholesalers, boarder areas, and sometime in district headquarters. In Taplejung district, demand is higher than production. Due to decrease the prices of Chirayita, district traders store the bough Chirayita in storage room until the prices of Chirayita would not raise (Figure 3 \& 4).

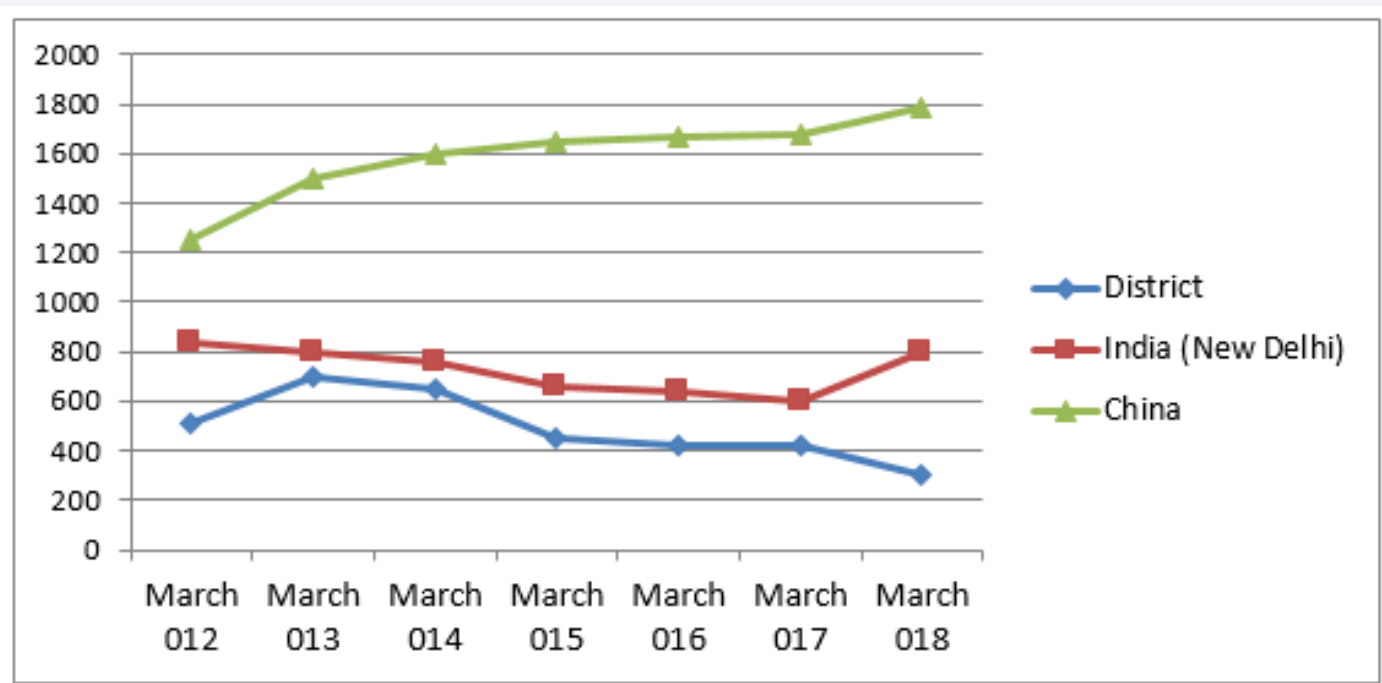

Figure 4: [14]

In Taplejung district, seven years price trends of Chirayita were analyzed. It was clearly seen that price of Chirayita in China is increasing compared to the previous years while the market price fluctuated in Nepal and India markets. Therefore, traders are interested to sell the Chirayita to China buyers. There is a big question mark on why price of Chirayita fluctuates in Nepal and India, and not in China. It was a bitter truth that professional Chirayita farmers are declining every year due to decrease the price of Chirayita. The Poverty Alleviation Fund (PAF) would play the catalytic role to ensure the fair markets to the Chirayita farmers. East region of Nepal is the prime production of Chirayita; therefore, proper cultivation of Chirayita focusing on poor, marginalized and disadvantaged people will be future

Table 1: Value chain upgrading strategies.

\begin{tabular}{|c|c|c|c|}
\hline Value Chain Level & Situation Analysis & Key Gaps & Intervention Activities \\
\hline Inputs and Services & $\begin{array}{l}\text { Farmers have cultivated the Chirayita in sloppy } \\
\text { and uncultivated areas in their own ideas and } \\
\text { knowledge. Farmers have not received any } \\
\text { facilities like quality seeds, JT/JTA, Agro vet, etc. }\end{array}$ & $\begin{array}{c}\text { Relay on other sources of } \\
\text { Chirayita Seeds, not technical } \\
\text { expertise. }\end{array}$ & $\begin{array}{l}\text { Quality Chirayita Seed production } \\
\text { (village based) Cooperative } \\
\text { investment on cultivation, soft } \\
\text { loan, etc. }\end{array}$ \\
\hline Production & $\begin{array}{c}\text { Production is only } 2-3 \mathrm{man} / \mathrm{Ropani} \text { (1 man } \\
=40 \mathrm{Kg})\end{array}$ & $\begin{array}{l}\text { Farmers used to broadcast the } \\
\text { seeds directly in the field with } \\
\text { minimum land preparation }\end{array}$ & $\begin{array}{c}\text { Support farmers for land } \\
\text { preparation, manure and } \\
\text { fertilizers, nursery management, } \\
\text { watering including soft loan } \\
\text { or revolving fund to Chirayita } \\
\text { cultivators. }\end{array}$ \\
\hline
\end{tabular}

programs considering the PAF strategies and guideline in order to enhance the socio-economic conditions of farmers. While selling the Chraito, making longer term agreements with China buyers is very important.

\section{Value chain mapping}

In case of Taplejung, $85 \%$ of total Chirayita production comes from the Chirayita cultivation and remaining $15 \%$ comes from either community forests or government managed forests. While comparing to value chain map of the previous years, buyers from Bangladesh have also interested. And Nepalese traders have been sold to Bangladeshi buyers since 2017. The value chain map of Chirayita has been prepared according to the field survey (2018). 


\section{International Journal of Environmental Sciences \& Natural Resources}

\begin{tabular}{|c|c|c|c|}
\hline Collection/Trading & $\begin{array}{c}\text { Immature harvesting, not appropriate post } \\
\text { harvesting technology }\end{array}$ & $\begin{array}{c}\text { Lack of technical experts on } \\
\text { Chirayita post-harvesting } \\
\text { techniques, Information gaps } \\
\text { on Chirayita prices. }\end{array}$ & $\begin{array}{c}\text { Training on post harvesting } \\
\text { technology, business information } \\
\text { system, orientation among } \\
\text { farmers, middleman and traders. }\end{array}$ \\
\hline Processing & $\begin{array}{c}\text { Limited processing of Chirayita, only cleaning, } \\
\text { drying and storing }\end{array}$ & $\begin{array}{c}\text { Lack of herbal extract, not any } \\
\text { product of Chirayita within the } \\
\text { district }\end{array}$ & $\begin{array}{c}\text { Formation of NTFPs cooperatives, } \\
\text { value addition (Pressuring, } \\
\text { packaging, branding), Chirayita } \\
\text { tea production, Chirayita powder }\end{array}$ \\
\hline End Market & $\begin{array}{c}\text { High demands on seedlings, price sensitivity, not } \\
\text { any grading system }\end{array}$ & $\begin{array}{c}\text { Market demands and gaps in } \\
\text { Chirayita production. }\end{array}$ & $\begin{array}{c}\text { Quality seedlings production, TOT } \\
\text { on the legal procedure of Chirayita } \\
\text { to Farmers, network building and } \\
\text { value addition }\end{array}$ \\
\hline Backward Linkage & $\begin{array}{c}\text { Lack of functional upgrading in value chain of } \\
\text { Chirayita }\end{array}$ & $\begin{array}{c}\text { Not the meaningful } \\
\text { coordination from producers } \\
\text { to final products }\end{array}$ & $\begin{array}{c}\text { Functional upgrading in overall } \\
\text { chain of Chirayita Value }\end{array}$ \\
\hline Forward Linkage & Just only sell the Chirayita after air/sun dried \\
form & $\begin{array}{c}\text { Lacks on collaboration } \\
\text { with herbal manufacturing } \\
\text { companies. }\end{array}$ & Chirayita product development \\
\hline
\end{tabular}

The figure illustrates the value chain map of Swertia chirayita. Now Bangladesh buyers have attracted towards Chirayita as

exporters. The existing value chain map of Chirayita in Taplejung as follows: (Figure 5 \& Table 1)

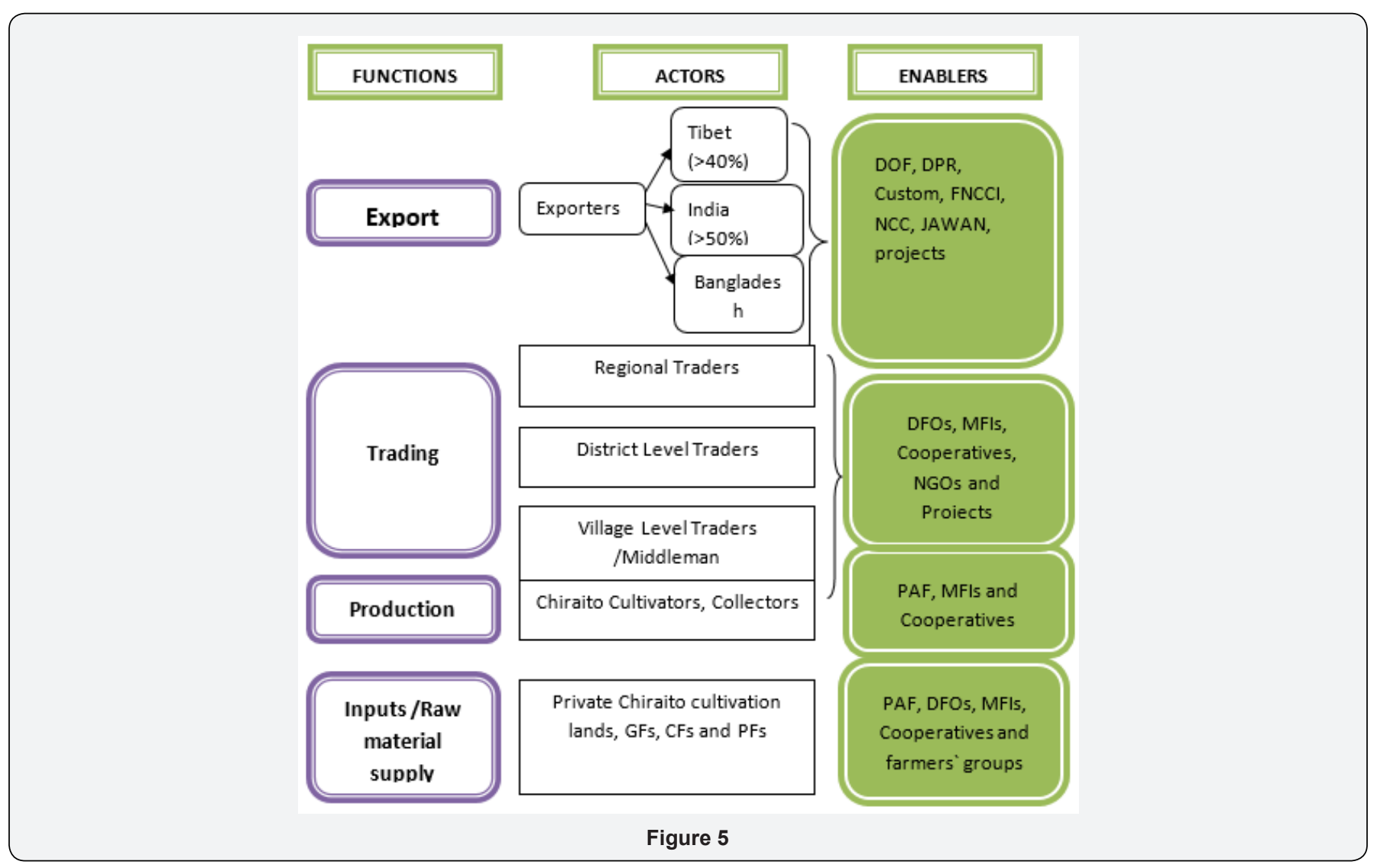

\section{Internal and external value chain financing}

While observing in the real field (Taplejung), Chirayita farmers have personally managed their financial matters themselves. Most of the people are under the poor and disadvantaged people. Therefore, PAF investment has also remarkably seen in the community in terms of providing the capacity building training to the rural farmers. Chirayita farmers are willing to extend their Chirayita farm if they got grants of financial support from PAF. However, they are cultivating the Chirayita in their farmlands of 3-4 Ropani lands. They will be able to cultivate at least 10 Ropani of their lands if they get the financial assistance from PAF as a soft loan through cooperatives or farmers` groups.

The PAF has provided the revolving fund of NRs 10, 00000 (10 Lakhs) to the Chirayita Cultivation Groups which made cultivators invest on promoting Chirayita cultivation. In the 
village level, only cooperative has been providing the loan to Chirayita farmers. In some case, farmers themselves managed for financial assets in order to start up the enterprises. Due to longer the returning period (about 2.5 years), MFIs almost deny for loan approval. Therefore, the PAF should invest among the poor and disadvantaged communities so that they would create income for livelihoods.

\section{Environmental analysis}

In Taplejung, the commercial cultivation of Chirayita is the main alternative adopted. Farmers cultivate maize and Chirayita on shifting cultivation lands. Chirayita grows best on freshly burned sloping land where there is enough rainfall and moderate sunlight. Compared to cardamom, Chirayita is less affected by pests and diseases. For Chirayita cultivation, the slashing and burning are done from March to May. Some farmers cultivate only Chirayita, while some cultivate it in between rows of maize plants. The Chirayita seeds are broad cast on shifting cultivation land. The plant usually takes around 18 months to mature, depending on the variety, soil fertility, and altitude. Farmers say that the Chirayita is ready to be harvested after three years. Harvesting is done in November and December [15].

Therefore, Chirayita should be promoted in private lands in the replace of other cereal crops. Farmers could use uncultivated/ barren lands for promoting Chirayita in order to increase the income of farmers sustainably. The PAF roles would be capacity building of farmers towards Chirayita cultivation along with leasing lands, insurance, soft loan or grants, value addition and marketing of Chirayita [16].

\section{Market analysis and strategy}

Commercial cultivation of Chirayita has been wide spread due to higher demands in China, India and Bangladesh markets. In the present situation (According to the field visit of Sirungkhim, Taplejung), there was an imbalance between market demands and gaps of Chirayita (Figure 6).

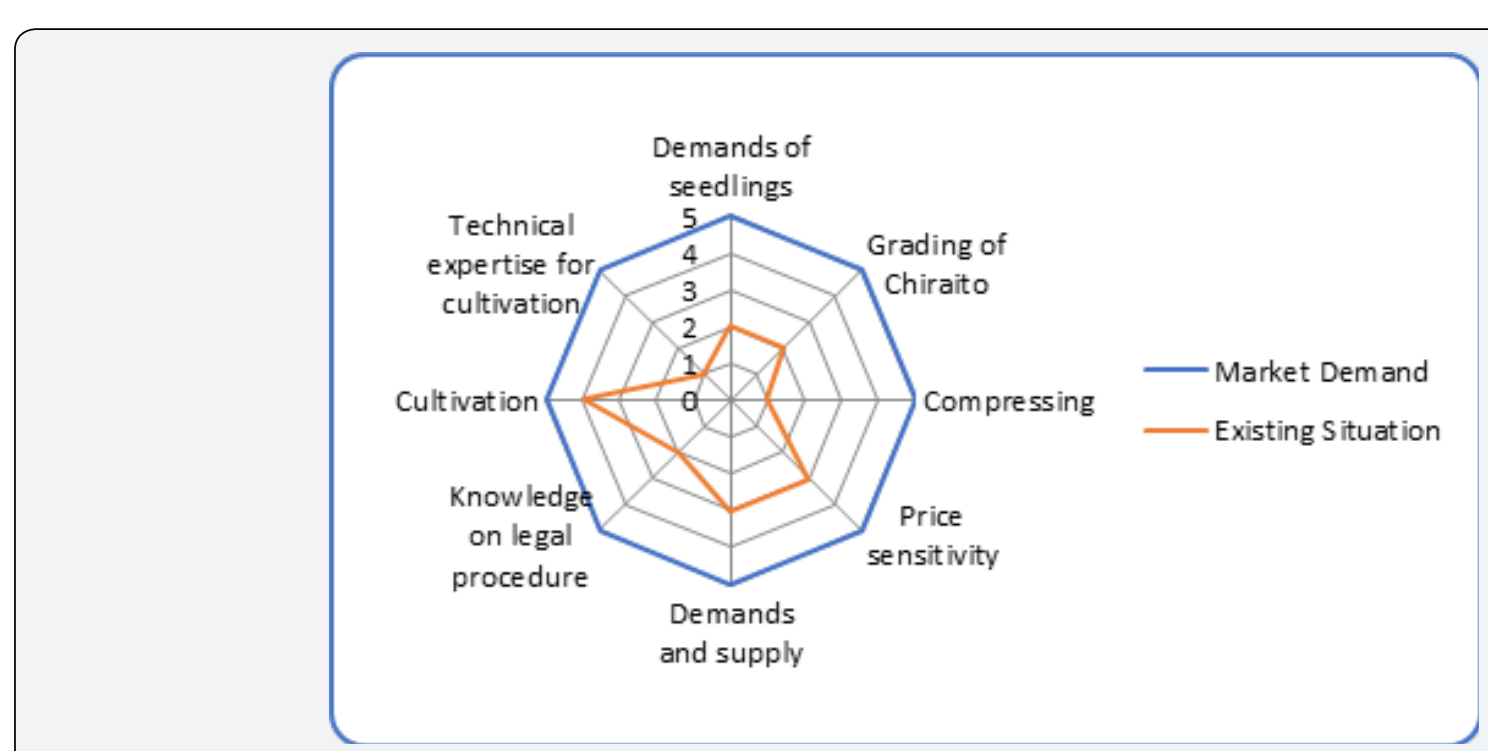

Figure 6: Market demands and gaps of Chirayita, (Source: FDF, Taplejung, 2018).

For the sustainable cultivation Chirayita farm, gaps are to be fulfilled by incorporating eight important indicators. In Nepal, 12 species of Chirayita trades under the name of Chirayita. While comparing the quality, Pothi Chirayita or Swertia chirayita is under first grade on the value system. Farmers have mixed up other species of Chirayita, and sell to middlemen or district traders. In the field, there was not any compressed Chirayita. As per FDGs. It was recorded that some professional farmers have used the Chirayita compressor for reducing the volume. The demand for Chirayita has been increasing day by day. During lowering the price, farmers or traders do not want to supply in the market. Chirayita price fluctuates according to demand in China and India. On the question of legal knowledge about trade, local farmers have not been aware of it. Farmers have many years of experiences and knowledge on cultivating practices of Chirayita. They have been cultivating for the past 20 years. However, they have not experienced technical experts, Collectors or farmers sell Chirayita to village level traders. Village level traders sell to the district level traders (bearing the transportation cost). Further, the district level traders sell this product in the regional markets, which is often situated in Terai regions (such as Nepalgunj, Krishnanagar, Bhairawaha, Biratnagar, and Kakadbhitta) and in Kathmandu. Regional traders export crude Chirayita to Indian and Tibetan market while very few are consumed within the country [11, 17-19].

\section{Current market channel}

$$
\begin{aligned}
& \text { Collector }->\text { Village Trader }->\text { Regional Trader }->\text { Exporter } \\
& \text { Collector }->\text { Village Trader }->\text { Exporter } \\
& \text { Collector }->\text { Village Trader }->\text { Regional Trader }->\text { Wholesaler }
\end{aligned}
$$
- >Exporter 
The price fluctuation of Chirayita and quantity of export totally depend on the market in India and China. At present, it seems that the demand from Tibet is increasing.

\section{Suggested alliance model}

For the functional upgrading of Chirayita, actors like farmers, young entrepreneurs, and traders play the vital role on VC analysis of Chirayita. The present function of farmers was to cultivate the Chirayita indigenously. Modern techniques on cultivation are required including TOT. Traders have accelerated to Birtamod and Tibet boarder. Therefore, further Chirayita networks should be established including sustainable seedling supply. In the present situation, cooperatives are engaged in savings and credit. The cooperative should provide the loan to farmers so that cultivators can stock Chirayita and sell it at right time (Table 2) [20-24].

Table 2: Suggested value Chian Alliance.

\begin{tabular}{|c|c|}
\hline Major Activities & Value Chian Alliance \\
\hline Sustainable cultivation & Farmers, Cooperaitves \\
\hline Royalty payment & DFO, CFUG \\
\hline Checking and weighing & Range Post or CFUG \\
\hline Release order or transit permit & DFO \\
\hline Local taxes & VDC, DDC, Municipality \\
\hline Checking and endorsement & Forest check post \\
\hline $\begin{array}{l}\text { The export recommendation, product certification and export } \\
\text { permission for selected natural products }\end{array}$ & $\begin{array}{l}\text { DFO (recommends the concern customs offices), DPR (permission to } \\
\text { export processed natural products that are prohibited for raw material } \\
\text { export) }\end{array}$ \\
\hline Certificate of origin & FNCCI/ DCCI, NCC \\
\hline Export permission and duty & Customs Office of exporting country \\
\hline Import permission and duty & Customs Office of importing country \\
\hline Market information & JABAN, AEC, ANSAB \\
\hline Financial support & NGOs, Cooperatives \\
\hline Processing technology & DCSI/ CSIDB, Private companies \\
\hline Resource management and Research & DPR, DFO, CFUG, NGO, Consultant \\
\hline Taxes & Inland Revenue Department, Department of Customs \\
\hline Enterprise registration & Office of Company Registrar, CSIDB/ DCSI, VDC \\
\hline
\end{tabular}

\section{Conclusion and Recommendations}

a) While comparing the marketing trends of Chirayita, it was observed that price trends are decreasing in India and Nepal. However, China market is in increasing order compared to previous years. 40 percent of the total production in Chirayita goes to China market which is more than 10 percent of the previous year (2017) in Taplejung. Agreement between Farmers' cooperative and buyers is essential for encouraging farmers' towards Chirayita cultivation.

b) The annual harvestable amount of Chirayita is 92 tons in Taplejung, and demand for Chirayita is 102 tons. The imbalance between market demands and Chirayita supply has been clearly seen. The middleman and traders used to store the Chirayita up to 2 years during price decreasing periods which create the big problem on market product supply.

c) For the Business development, there are four important issues (market information, access to market, technology and product development, and input suppliers). In the present situation, coordination and linkages among village, district, and regional level traders are essential to know the updated price list of Chirayita. Agro vets, nurseries and lead farmers used to supply the seeds. Therefore, quality seeds should be ensured in the village which is more productive and disease resistant in comparing to seeds from outsiders.

d) 200-500gm is required per hectare. Farmers have been using the direct seeds broadcasting techniques in sloppy and unutilized lands (Pakho Bari). According to the FDG, we knew that transplanted seedlings increase the productivity two times with regular watering and organic manure. Famers of Taplejung have been the relay on seeds from neighbor`s district Illam. Quality seeds should be produced in local level for promoting Chirayita enterprise in a long run.

e) No doubt, farmers can produce Chirayita after at least 2.5 years. There are high demands of Chirayita, but farmers also imposed to store harvested Chirayita due to lowering market price. Therefore, the PAF should study on marketing channel, and be finding out the possible markets where Chirayita price would be high.

f) Local farmers used to clean, make air dry, store, compress and sell to middlemen or district traders as post 
harvesting techniques. Besides these, no more value addition of Chirayita in Nepal. Further value addition of Chirayita has been recommended in the village or district level, led by cooperatives.

\section{References}

1. GoN/MOFSC/ DPR (2006) Prioritized Medicinal Plants for Economic Development in Nepal. Department of Plants Resources. Ministry of Forest and Soil Conservation, Government of Nepal, Kathmandu.

2. Pyakurel D, Baniya A (2011) NTFPs: Impetus for Conservation and Livelihood Support in Nepal. A Reference Book on Ecology, Conservation, Product Development and Economic Analysis of Selected NTFPs of Langtang Area in the Sacred Himalayan Landscape. WWF Nepal.

3. Joshi P, Dhawan Vibha (2005) Swertia chirayita - An overview. Current Science 89(4): 635-640.

4. Pyakurel D, Chapagain SP (2014) Diagnosing Barriers for Value Chain Development of Chireeta and Pig. Report submitted by White Lotus Center to Asian Development Bank, Nepal.

5. Kumar V, Van Staden J (2016) A Review of Swertia chirayita (Gentianaceae) as a traditional medicinal plant. Front Pharmacol 6: 308.

6. Tabassum S, Mahmood S, Hanif J, Hina M, Uzair B (2012) An Overview of Medicinal Importance of SWERTIA CHIRAYITA. International Journal of Applied Science and Technology 2(1): 298-304.

7. Shukla JK, Dhakal P, Uniyal RC, Paul N, Sahoo D (2017) Ex-situ cultivation at lower altitude and evaluation of Swertia chirayita, a critically endangered medicinal plant of Sikkim Himalayan region, India. S Afr J Bot 109: 138-145.

8. Department of Plant Resources (2006) Medicinal Plants Prioritized for Economic Development in Nepal (in Nepali). Ministry of Forests and Soil Conservation, Department of Plant Resources, Thapathali.

9. MoFSC 2069 (BS) Hamro Ban. Government of Nepal (GoN), Ministry of Forest and Soil Conservation (MoFSC), Kathmandu.

10. MoFSC 2070 (BS) Hamro Ban. Government of Nepal (GoN), Ministry of Forest and Soil Conservation (MoFSC), Kathmandu.
11. Pyakurel D, Oli BR (2013) Market study of tradable and economically important medicinal and Aromatic plants of Eastern Nepal, Department of Plant Resources, Kathmandu.

12. He J, Yang B, Dong M, Wang Y (2018) Crossing the roof of the world: Trade in medicinal plants from Nepal to China. J Ethnopharmacol 224: $100-110$

13. Cunningham AB (2017) Production from both wild harvest and cultivation: the cross-border Swertia chirayita (Gentianaceae) trade. School of Life Sciences, University of KwaZulu-Natal, King Edward Avenue, Pietermaritzburg, 3209, South Africa.

14. ANSAB (2016) Price lists of Non-Timber Forest Product.

15. Phuntsho K, Aryal KP, Kotru R (2015) Shifting cultivation in Bangladesh, Bhutan and Nepal: Weighing government policies against customary tenure and institutions. ICIMOD Working Paper 2015/7. Kathmandu: ICIMOD.

16. Cunningham AB, Brinckmann JA, Schippmann U, Pyakurel D (2018) Production from both wild harvest and cultivation: the cross-border Swertia chirayita (Gentianaceae) trade. Journal of Ethnopharmacology 225: 42-52.

17. ANSAB (2014) Market Information System (MIS). Asia Network for Sustainable Agriculture and Bio Resources.

18. DOF (2016) Hamro Ban.

19. http://dof.gov.np/image/data/publication/All_Yearly_Publications/ Hamro\%20ban_2073.pdf

20. http://www.intracen.org/itc/blogs/market-insider/Chirata-herbfarming-in-Nepal-increasing-household-income/

21. Kumar V (2016) A Review of Swertia chirayita as a traditional medicinal plant, Research Centre for Plant Growth and Development, School of Life Science, University of Kwazulu-Natal, South Africa.

22. Pant SR (2004) Genetic Diversity in Swertia Species (Gentianaceae) of Nepal. An M.Sc. Thesis submitted to Central Department of Botany, Tribhuvan University, Kirtipur, Kathmandu, Nepal.

23. Pyakurel D (2008) Resource Assessment of Chirayita (Swertia chirayita) in Langtang Nepal.

24. The Mountain Institute (TMI) (2014) Chirata Herb Farming in Nepal Increasing Household Income. WWF, Nepal.

This work is licensed under Creative

Commons Attribution 4.0 License

DOI: 10.19080/IJESNR.2019.20.556027
Your next submission with Juniper Publishers will reach you the below assets

- Quality Editorial service

- Swift Peer Review

- Reprints availability

- E-prints Service

- Manuscript Podcast for convenient understanding

- Global attainment for your research

- Manuscript accessibility in different formats

( Pdf, E-pub, Full Text, Audio)

- Unceasing customer service

Track the below URL for one-step submission https://juniperpublishers.com/online-submission.php 